\title{
Correction to: CircDLST promotes the tumorigenesis and metastasis of gastric cancer by sponging miR-502-5p and activating the NRAS/MEK1/ERK1/2 signaling
}

Jing Zhang ${ }^{1 *+}$, Lidan Hou ${ }^{2+}$, Rui Liang ${ }^{1 \dagger}$, Xiaoyu Chen ${ }^{1}$, Rui Zhang ${ }^{1}$, Wei Chen ${ }^{1}$ and Jinshui Zhu ${ }^{1 *}$

\section{Correction to: Mol Cancer 18, 80 (2019)}

https://doi.org/10.1186/s12943-019-1015-1

Following publication of the original article [1], the authors found an error in Fig. 7d, e. The correct figure is shown below.

\section{Author details}

'Department of Gastroenterology, Shanghai Jiao Tong University Affiliated Sixth People's Hospital, No. 600 Yishan Road, Shanghai 200233, China.

2Department of Gastroenterology, Shanghai Ninth People's Hospital, Shanghai Jiao Tong University School of Medicine, Shanghai, China.

Published online: 12 August 2020

\section{Reference}

1. Zhang J, Hou L, Liang R, Chen X, Zhang R, Chen W, Zhu J. CircDLST

promotes the tumorigenesis and metastasis of gastric cancer by sponging miR-502-5p and activating the NRAS/MEK1/ERK1/2 signaling. Mol Cancer. 2019;18:80. https://doi.org/10.1186/s12943-019-1015-1.

*Correspondence: jing5522724@vip.163.com; zhujs1803@163.com

${ }^{+}$Jing Zhang, Lidan Hou and Rui Liang contributed equally to this work.

'Department of Gastroenterology, Shanghai Jiao Tong University Affiliated Sixth People's Hospital, No. 600 Yishan Road, Shanghai 200233, China

Full list of author information is available at the end of the article

(c) The Author(s). 2020 Open Access This article is licensed under a Creative Commons Attribution 4.0 International License, which permits use, sharing, adaptation, distribution and reproduction in any medium or format, as long as you give appropriate credit to the original author(s) and the source, provide a link to the Creative Commons licence, and indicate if changes were made. The images or other third party material in this article are included in the article's Creative Commons licence, unless indicated otherwise in a credit line to the material. If material is not included in the article's Creative Commons licence and your intended use is not permitted by statutory regulation or exceeds the permitted use, you will need to obtain permission directly from the copyright holder. To view a copy of this licence, visit http://creativecommons.org/licenses/by/4.0/ The Creative Commons Public Domain Dedication waiver (http://creativecommons.org/publicdomain/zero/1.0/) applies to the data made available in this article, unless otherwise stated in a credit line to the data. 


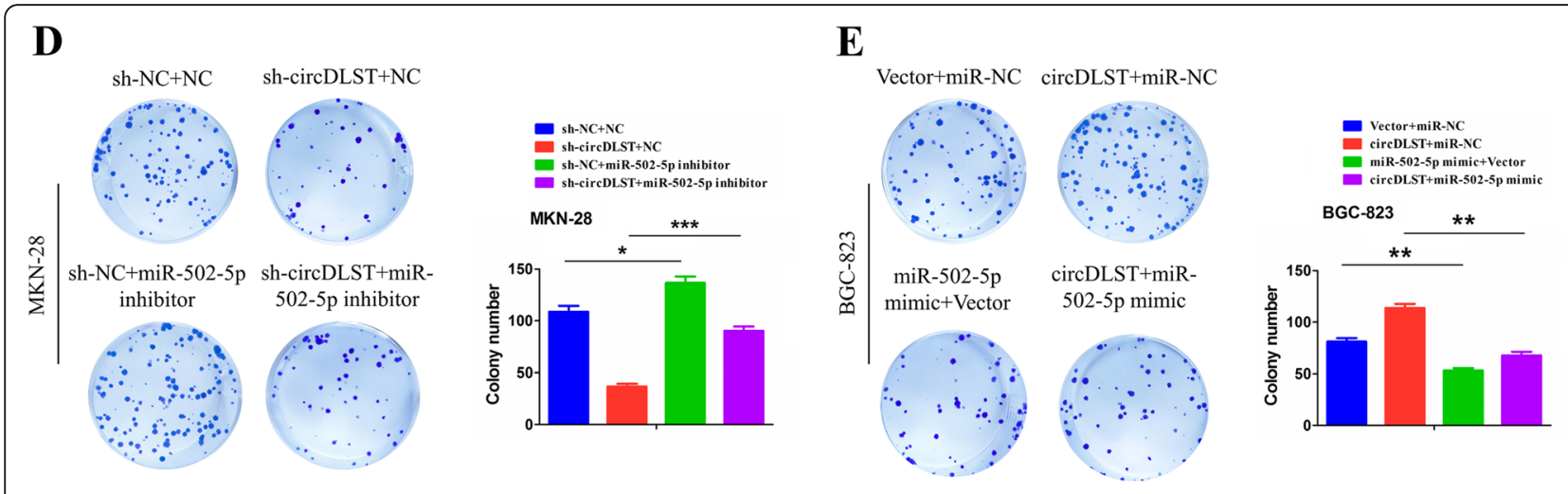

Fig. 7 d, e Colony formation analysis of the colony number after the co-transfection of miR-502-5p inhibitor and sh-circDLST in MKN-28 cells or miR-502-5p mimic and circDLST in BGC-823 cells. Data are the means \pm SEM of three experiments. ${ }^{*} P<0.05$; ${ }^{* *} P<0.01 ;{ }^{* * *} P<0.001$ 